\title{
THE ABBEY OF ST. CHRYSOGONUS IN ZADAR - BETWEEN EARLY CHRISTIAN SCULPTURE AND THE ROMANESQUE ARCHITECTURE
}

\section{IVAN JOSIPOVIĆ, IVANA TOMAS}

UDC: $726.71(497 \cdot 581.1) " 09 "$

Review

Manuscript received: 28. 02. 2017.

Revised manuscript accepted: 16. 03. 2017.

DOI: 10.1484/J.HAM.5.113721
I. Josipović

History of Art Department, University of Zadar Obala kralja Petra Krešimira IV. 2, 23 ooo Zadar, Croatia

I. Tomas

Faculty of Humanities and Social Sciences, University of Zagreb Ivana Lučića 3, 10 ooo Zagreb, Croatia

The monastery of St. Chrysogonus in Zadar was one of the most notable Benedictine abbeys on the eastern Adriatic coast. The monastery was first mentioned in the second half of the tenth century, but there is very little knowledge about the earliest (Benedictine) building. The presentday church of St. Chrysogonus, consecrated in 1175, is a monumental three-nave basilica and one of the most significant Romanesque religious monuments in the eastern Adriatic. One of the aims of the paper is to discuss the problem of the first church and monastery of St. Chrysogonus - therefore special attention will be given to the interpretation of Early Christian and Early Medieval fragments of liturgical furnishings and architectural decoration found in the well-preserved Romanesque monument. Attention will also be focused on the Romanesque church, especially on the interpretation of its architecture and surviving remains of architectural sculpture, and architectural influences that has always been in the centre of scientific interest. The purpose of this paper is to improve the existing knowledge of the Benedictine monastery in Zadar, which will contribute to a better understanding of Benedictine (medieval) monuments of the eastern Adriatic coast and the adjacent area.

Keywords: monastery of St. Chrysogonus, Zadar, Early Christian sculpture, pre-Romanesque reliefs, Romanesque architecture, middle Ages

The abbey of St. Chrysogonus is one of the most notable Benedictine abbeys on the eastern Adriatic coast. It was mentioned indirectly for the first time in the will of the Zadar prior Andrew which is generally dated to December of 918. ${ }^{1}$ The will states that prior Andrew leaves land and vineyards in the village of Diklo near Zadar to the church of St. Chrysogonus. Abbot Odolbertus (abbas Odolbertus) was also endowed on the same occasion. He is mentioned as one of the ten witnesses, and his name - Odolberti abbatis - was mentioned at the end of the document after the bishop of Zadar Firminus (Formini). On the basis of these two facts it is assumed that Odolbertus was the prior of the abbey of St. Chrysogonus. ${ }^{2}$ His Germanic name - as well as the names of two other Benedictine monks (Gottschalk and Theudebertus) present in the region in the $9^{\text {th }} \mathrm{c}$. - suggests their origin in the Frankish Empire.

The next important document is dated to December 19, 986, with explicit mention of the Benedictines in Zadar for the first time. ${ }^{3}$ In it the prior of Zadar and proconsul of Dalmatia Maius, with approval of the city dignitaries and general population, donates the church of St. Chrysogonus to the renewed Benedictine community led by Abbot Madius who returned from the abbey in Monte Cassino that year.
The document mentions that the church located within the city walls which houses the body of St. Chrysogonus was built by priors (mayors) of Zadar Fuscolo and Andrew at a place of former monastery, extinct owing to negligence. On that occasion the church was renovated and joined with the "old cloister" i.e. monastery, located north of it as they were divided by a street. On this occasion the road between the newly renovated church and the old cloister was closed. ${ }^{4}$

From that moment the abbey of St. Chrysogonus started to grow in its rights and estates. For instance, until the beginning of the 12th century it received privileges from many donors as evident from the charters of Croatian kings Michaelus Krešimir II and Petrus Krešimir IV. 5 We will only mention that citizens of Zadar ceded to the abbey in 1036 "a garden in front of the church of St. Thomas", in reality a garden situated in between the two churches. This is the area in which later Romanesque basilica of St. Chyrsogonus was built and consecrated in $1175 .{ }^{6}$ This church has been preserved to the present day (fig. 1).

Incorporation of the abbey area into insulae of the Roman-era city and finds of Early Christan and pre-Romanesque sculpture in the existing church of St. Chrysogonus, but also in the area of the entire abbey indicate the possibility

${ }^{1}$ Codex diplomaticus regni Croatiae, Dalmatiae et Slavoniae / Diplomatički zbornik Kraljevine Hrvatske, Dalmacije i Slavonije, 1, (ed.) Marko Kostrenčić, Jakov Stipišić, Miljen Šamšalović, Zagreb, 1967, pp. 25-28.

${ }^{2}$ More detail in: Ć. M. IVEKOVIĆ, Crkva i samostan Sv. Krševana u Zadru - hrvatska zadužbina iz X. stoljeća, Zagreb, 1931, 14; I. OSTOJIĆ, Benediktinci u Hrvatskoj i ostalim našim krajevima, II, Benediktinci u Dalmaciji, Split, 1964, p. 39; I. MUSTAĆ, Cartula traditionis ecclese Beati Chrysogoni martiris iz 986. godine, in: 1000 godina Samostana Svetog Krševana u Zadru: prilozi sa znanstvenog skupa održanog 11. i 12. prosinca 1986. u Zadru, u povodu 1000. obljetnice Samostana Svetog Krševana i zo. obljetnice Filozofskog fakulteta u Zadru, (ed.) Ivo Petricioli, Zadar, 199o, p. 28.

${ }^{3}$ Codex diplomaticus..., op. cit. (n. 1), pp. 44-46.

${ }^{4}$ See more in: I. OSTOJIĆ, op. cit. (n. 2), pp. 40-41; I. MUSTAĆ, op. cit. (n. 2), 23 and passim; P. VEŽIĆ, Opatija Sv. Krševana u Zadru - razvoj prostorne cjeline, in: 1000 godina Samostana Svetog Krševana u Zadru: prilozi sa znanstvenog skupa održanog 11. i 12. prosinca 1986. u Zadru, u povodu 10oo. obljetnice Samostana Svetog Krševana i 30. obljetnice Filozofskog fakulteta u Zadru, (ed.) Ivo Petricioli, Zadar, 1990, p. 167.

${ }_{5}^{5}$ Codex diplomaticus..., op. cit. (n. 1), pp. 44, 105-109, 112-114; P. ŽIVKOVIĆ, Posjedi i prihodi Samostana Svetog Krševana u Zadru od osnivanja do konca XV. stoljeća, in: 1000 godina Samostana Svetog Krševana u Zadru: prilozi sa znanstvenog skupa održanog 11. i 12. prosinca 1986. u Zadru, u povodu 10oo. obljetnice Samostana Svetog Krševana i zo. obljetnice Filozofskog fakulteta u Zadru, (ed.) Ivo Petricioli, Zadar, 1990, pp. 111-113 and passim.

${ }^{6}$ P. VEŽIĆ, op. cit. (n. 4), pp. 167, 169. 


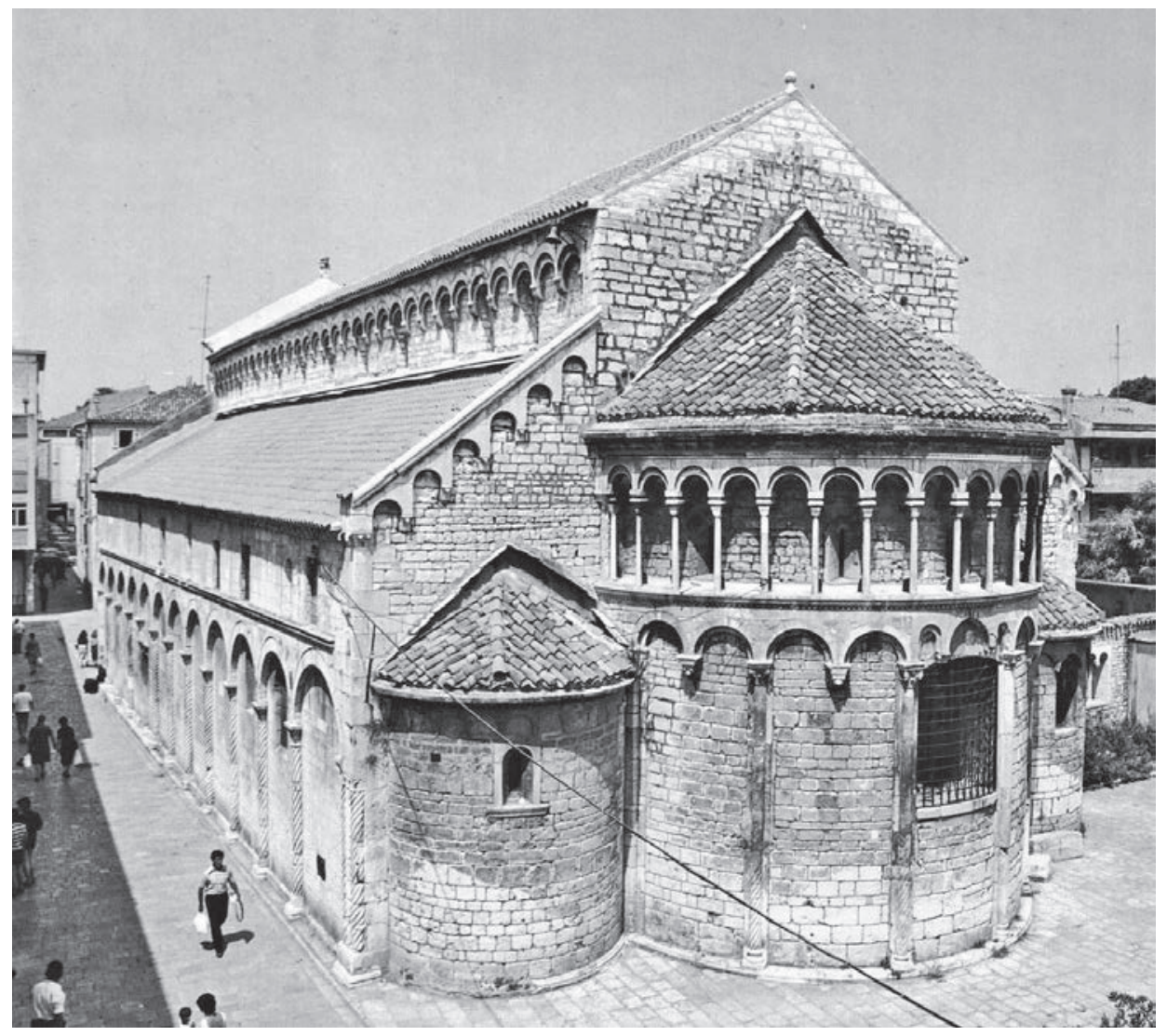

Fig. 1. Zadar, St. Chrysogonus church, second half of 12th century (photo: Emil Hilje)

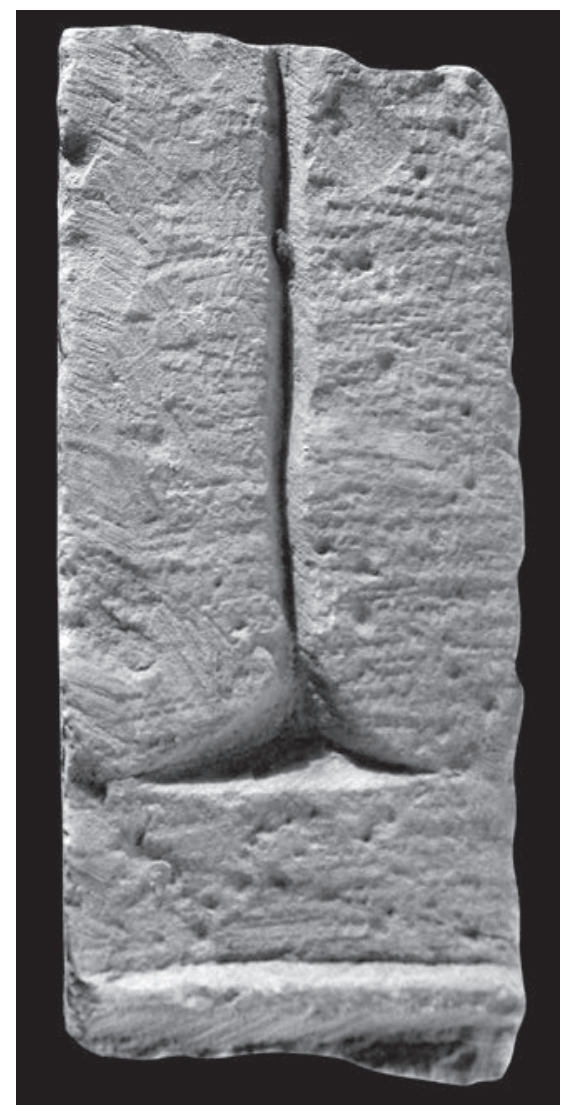

Fig. 2. Fragment of a small mullion with incised cross (A. MIŠKOVIĆ, op. cit. (n. 7), p. 71)

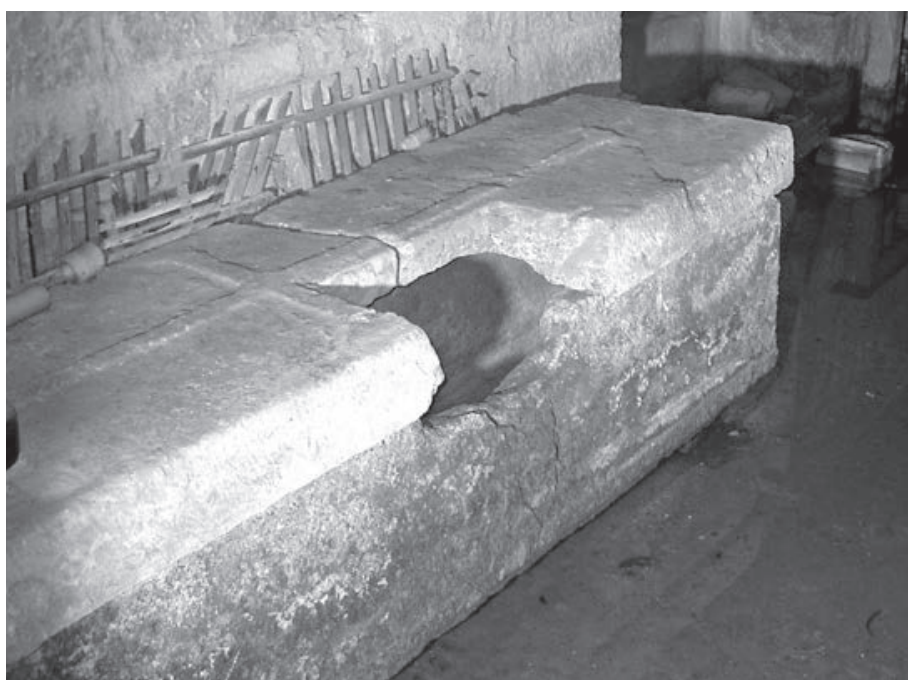

Fig. 3. Sarcophagus whose flat lid bears a carved Latin cross (A. MIŠKOVIĆ, op. cit. (n. 7), p. 72)

that the church existed there as early as the Early Christian period and that it became a part of larger complex of the Benedictine abbey during the Early Middle Ages. Regarding the Early Christian finds three reliefs should be mentioned, dated broadly to the period from the 4 th to the 7 th century: they include a fragment of a small mullion with incised cross (fig. 2), a sarcophagus whose flat lid bears a carved Latin cross (the sarcophagus is now located in the "crypt" under the back part of the southern aisle of the church; fig. 3), and the funerary piscina of Aurelia Corconia which was found

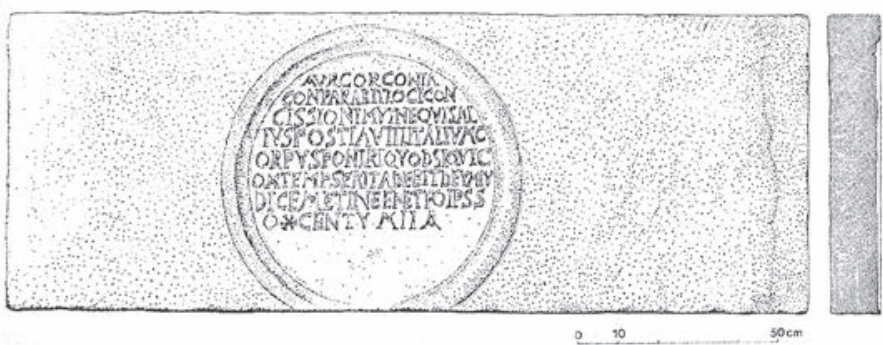

Fig. 4. Drawing of funerary piscina of Aurelia Corconia (A. MIŠKOVIĆ, op. cit. (n. 7), p. 73)

in 1888 during church renovation in its pavement (fig. 4). ${ }^{7}$ Furthermore, two Early Christian spoliae are visible on the inner side of the lunette of the main Romanesque church portal. They refer to a column fragment and a fragment of slab with relief depicting doubled Latin crosses at whose tops we find an unusual motif resembling a shell (fig. 5). The latter two fragments were carved in marble distinguishing them from other Early Christian reliefs found in Zadar.

As opposed to the Early Christian fragments which are scarce and which may have ended in this church from one or perhaps even several sites in the city, pre-Romanesque sculptures are more abundant and they can be classified into two homogeneous groups in stylistic and morphological terms. This indicates that these were not randomly collected spoliae but fragments belonging to liturgical furnishings of the older (monastery) church. In the previous scholarly literature this was neglected because most of these fragments remained unknown and without proper interpretation, ${ }^{8}$

${ }_{7}$ See more in: A. MIŠKOVIĆ, Liturgijski ambijenti i instalacije ranokršćanskog razdoblja na zadarskom području, II, Katalog (doctoral thesis), Zagreb, 2012, 71-73, with overall bibliography.

${ }^{8}$ Authors would like to thank Jakov Vučić, director of the Archaeological Museum in Zadar, and Robert Maršić, employee of the mentioned institution, who allowed us to see all the fragments and related documentation enabling in that way some conclusions which will be presented in the forthcoming text. 


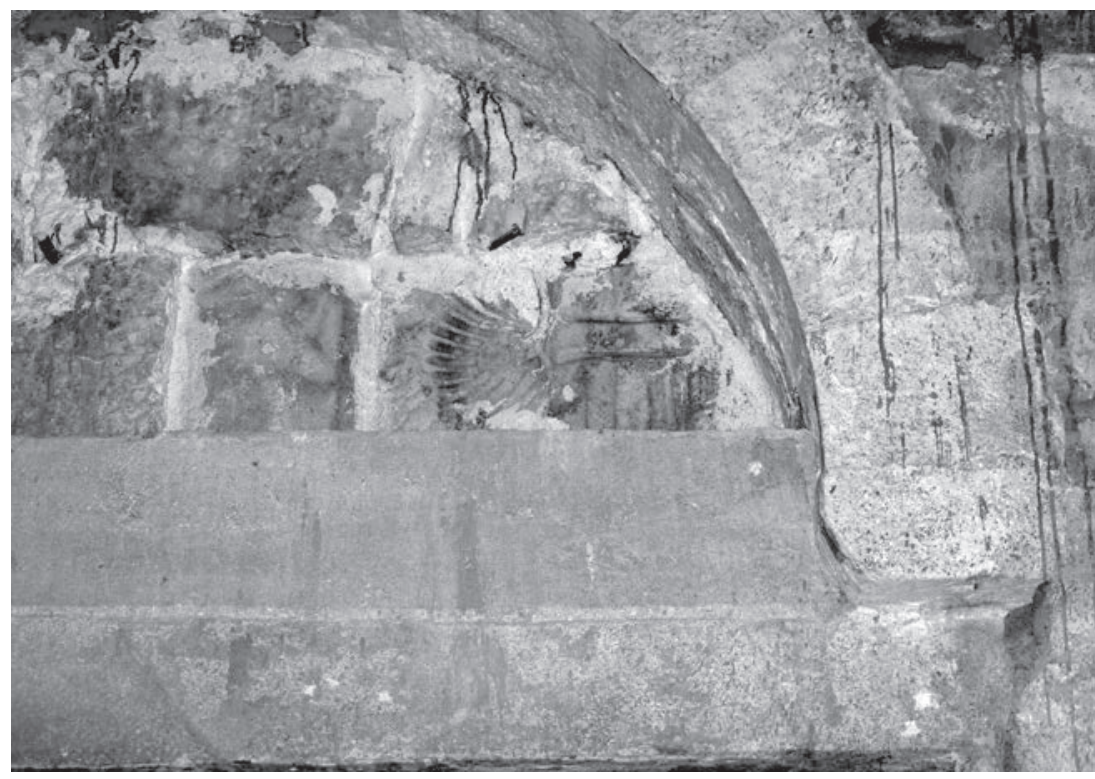

Fig. 5. Two Early Christian spolia pieces on the inner side of the lunette of the main Romanesque church portal (photo: Ivan Josipović)

although most of them were found during the renovations of the church of St. Chrysogonus in 1888 and 1912, and some were even published at the end of the 19th century. ${ }^{9}$

The first group of mature pre-Romanesque reliefs consists of nine fragments only one of which has been previously analyzed (fig. 6-7). It is a fragment of an architrave of a chancel screen with carved inscription of certain donor who had it made together with his wife Marina (fig. 6c). Ivo Petricioli noticed the similarity of this architrave with two architraves from Muć and Nin bearing the name of the Croatian Duke Branimir (fig. 8b-c). ${ }^{10}$ Furthermore, Nikola Jakšić recognized other works similar to these architraves and associated them with a stonecarvers' workshop whose activity was recognized at almost twenty sites on

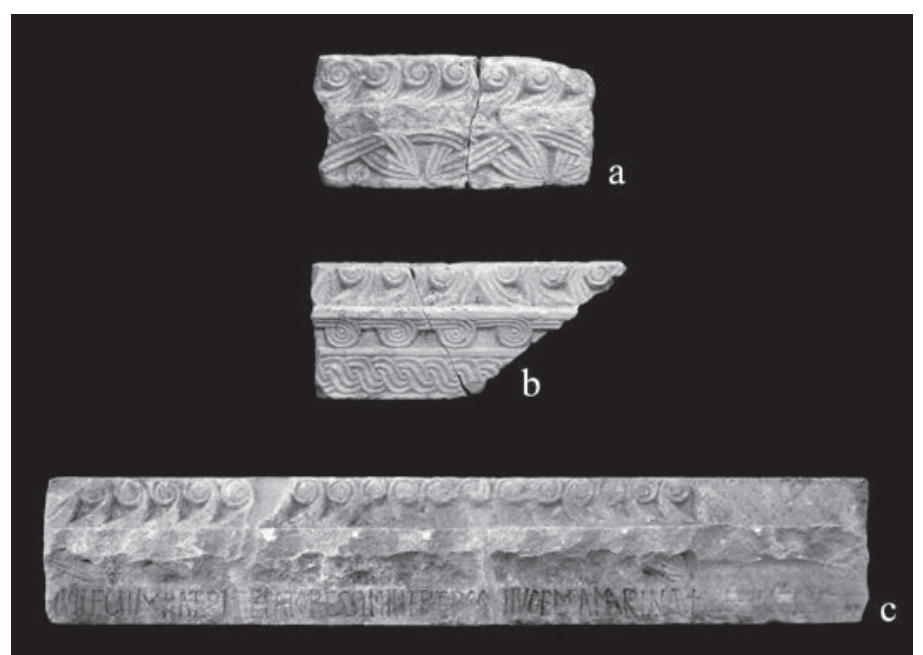

Fig 6. Benedictine Stonecarvers' Workshop from the Period of Duke Branimir, Fragments found in St. Chrysogonus church, last decade of 9th century the territory of the Croatian dukedom, but also in some Dalmatian cities." Moreover, the name of Abbot Theudebertus carved on the architrave from Nin (fig. 8d), its mention on the fragments from Lepuri (fig. 8e) in the hinterland of Zadar where activity of the same workshop was confirmed, ${ }^{12}$ as well as mentioning of St. Chrysogonus as a patron saint on the entablature of the chancel screen with identical morphological characteristics from the church in the village of Otres in the hinterland of Šibenik (fig. 8f), ${ }^{13}$ were arguments used by Jakšić to associate the activity of the mentioned workshop with the Benedictines whose most important abbey on the eastern Adriatic coast was exactly St. Chrysogonus in Zadar. That is why Jakšić calls this workshop the Benedictine stonecarvers' workshop from the period of Duke Branimir.

We can say that other pre-Romanesque fragments found in the church of St. Chrysogonus which exhibit workmanship features and specific Morellian details characteristic of the Benedictine stonecarvers' workshop confirm all previous conclusions which have already been presented in scholarly literature. Decoration of these reliefs corresponds fully to regular visual repertory of recognized products of the mentioned stonecarvers' workshop. Namely, in addition to the mentioned architrave of the chancel screen, eight more similar fragments were found in St. Chrysogonus belonging to pilasters, slabs and architraves of the chancel screen (fig. 6a, 7c-e), and three fragments most probably belonged to a ciborium (fig. 6b, 7a-b). There are many possible analogies between these fragments and other reliefs of this stonecarvers' workshop from a number of sites in the region of central and northern Dalmatia. We will mention only some of them. For example, two small fragments of the ciborium from St.

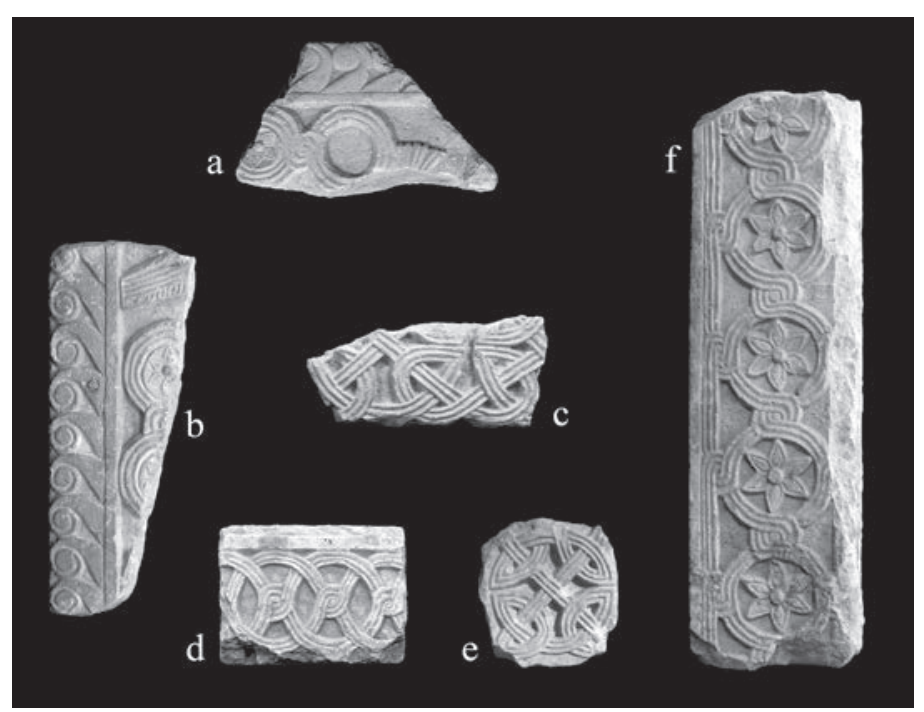

Fig. 7. Benedictine Stonecarvers' Workshop from the Period of Duke Branimir, Fragments found in St. Chrysogonus church, last decade of 9th century

\footnotetext{
${ }_{9}^{9}$ L. BENEVENIA, Scampoli di storia patria, Zara, 1890, p. 204; G. SMIRICH, La collezione dei monumenti medioevali nel Museo di S. Donato in Zara, Ephemeris Bihačensis, Zara, 1894, p. 18, no. 19-23.

${ }^{10}$ I. PETRICIOLI, Umjetnička baština Samostana Sv. Krševana do 16. stoljeća, in: 1000 godina Samostana Svetog Krševana u Zadru: prilozi sa znanstvenog skupa održanog 11. i 12. prosinca 1986. u Zadru, u povodu 10oo. obljetnice Samostana Svetog Krševana i zo. obljetnice Filozofskog fakulteta u Zadru, (ed.) Ivo Petricioli, Zadar, 1990, p. 198.

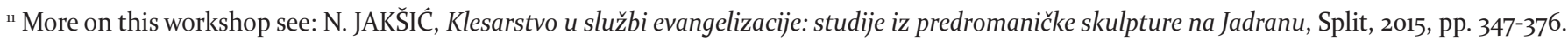

${ }^{12}$ N. JAKŠIĆ, op.cit. (n. 11), pp. 340-346.

${ }^{13}$ V. DELONGA, The Latin Epigraphic Monuments of Early Mediaeval Croatia, Split, 1996, pp. 228-229, Pl. LXXI.
} 
a

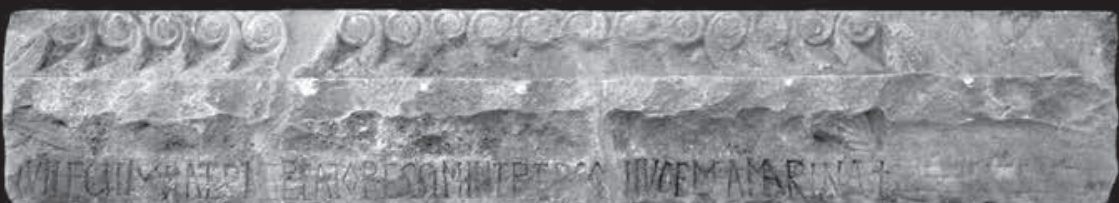

Zadar, St. Chrysogonus

...QVI LEGITIS ORATE P(ro) ME PECATORES SIMILITER ET P(ro) CONIVGE MEA MARINA +

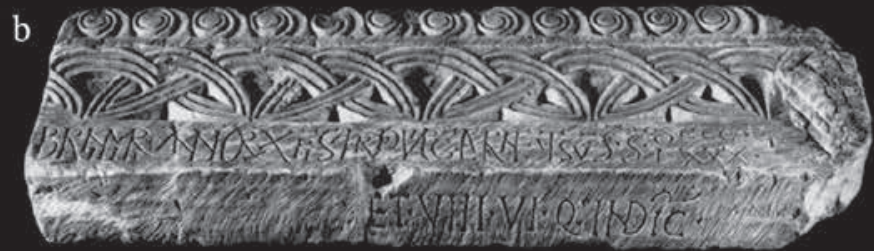

Muć near Split

[temporibus dom(i)ni ducis/principis] BRANIMIRI ANNOR(vm) CHR(ist)I SACRA DE VIRG(ine)

CARNE(m) VT SV(m)P(sit) S[acrvm] DCCCLXXX ET VIII VIQ(ve) INDIC(TIONE)

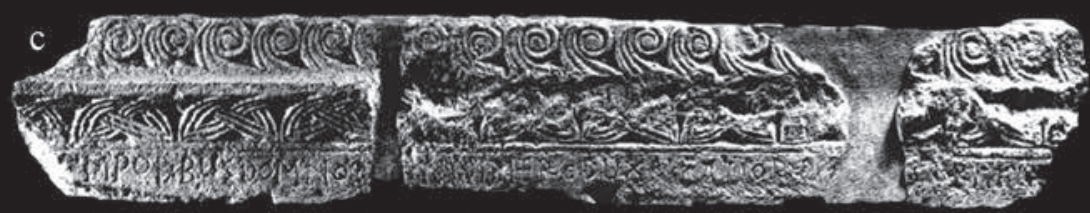

Nin near Zadar, St. Ambrose monastery church

[...t]EMPORIBUS DOM(i)NO B(ra)NNIMERO DUX SLCAUORUM [...]

d

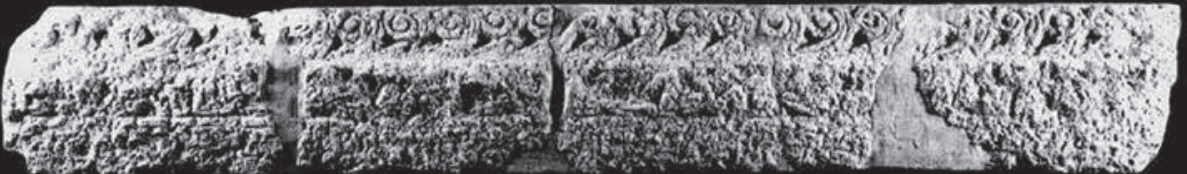

Nin near Zadar, St. Ambrose monastery church

EGO TEUDEBERTUS ABBA(s) PRO REMEDIO ANIME MEE FIERI ROG[avi]...

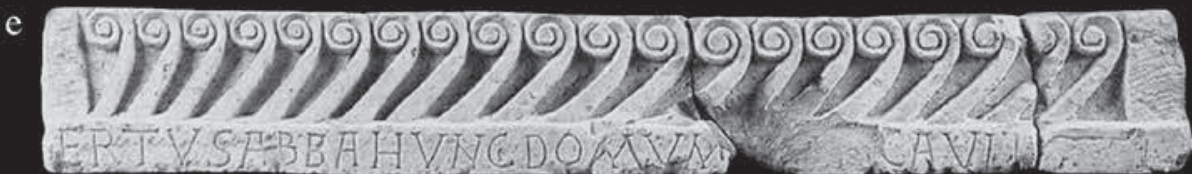

Lepuri near Benkovac, St. Martin monastery church

[Teodeb]ERTUS ABBA HVNC DOMUM (edifi)CAVIT...

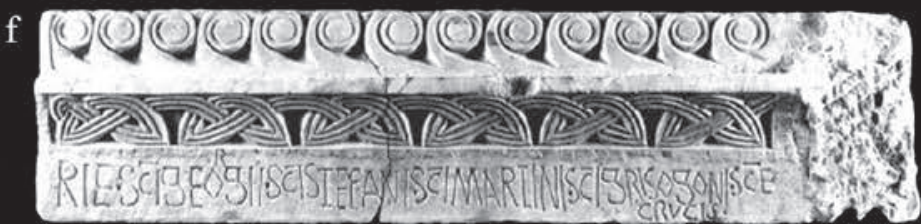

Otres near Šibenik, probably St. Martin church

[ad ho]NORE(m) BEATI PETRI ET S(an)C(ta)E MA]RIE S(an)C(t)I GEORGII

$\mathrm{S}(\mathrm{an}) \mathrm{C}(\mathrm{t})$ I STEFANI S(an)C(t)I MARTINI S(an)C(t)I GRISOGONI S(an)C(ta)E CRVCIS

Fig. 8. Architraves with epigraphic inscriptions from Zadar, Muć, Nin, Lepuri and Otres

Chrysogonus are very similar to gable fragments from the village of Kula Atlagić near Zadar and Uzdolje and Biskupija near Knin (fig. 9). In addition, rendering and manner of decoration of well preserved pilaster from St. Chrysogonus with five knotted triple-banded circles filled with sexfoil flowers is very similar to a pilaster from the site of Crkvina 


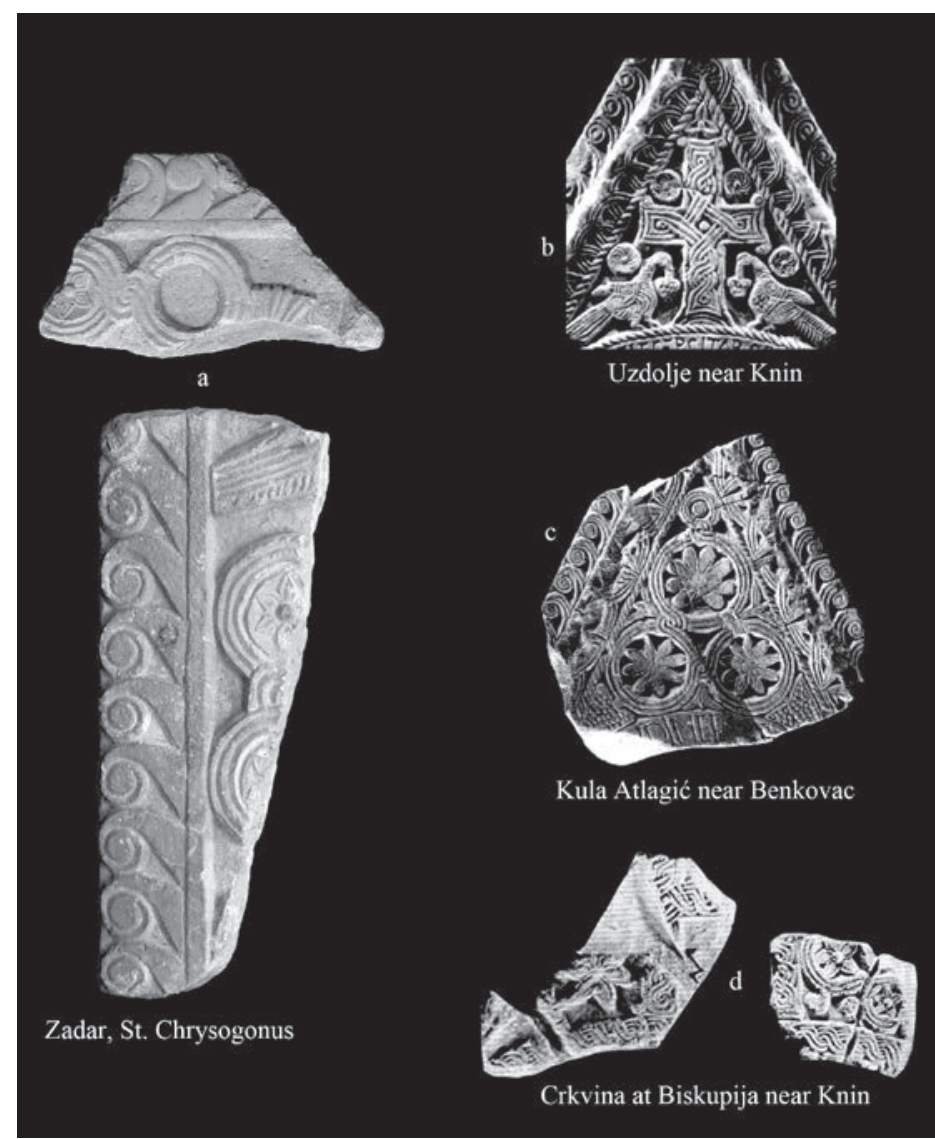

Fig. 9. Benedictine Stonecarvers' Workshop from the Period of Duke Branimir, Comparison of fragments of the chancel screen and ciborium from Zadar, Uzdolje, Kula Atlagić and Biskupija near Knin

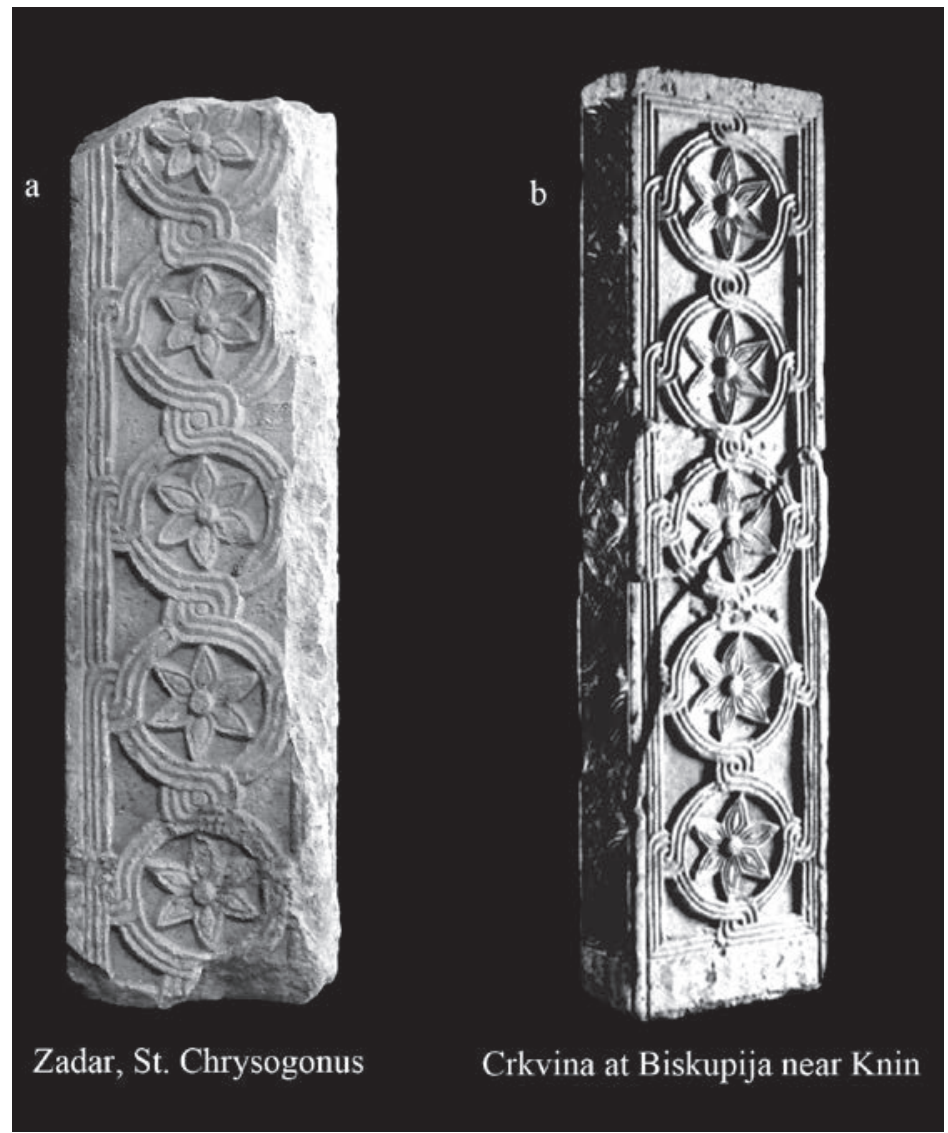

Fig. 10. Benedictine Stonecarvers' Workshop from the Period of Duke Branimir Comparison of fragments of the same parts of the chancel screen (pilasters) from Zadar and Biskupija near Knin

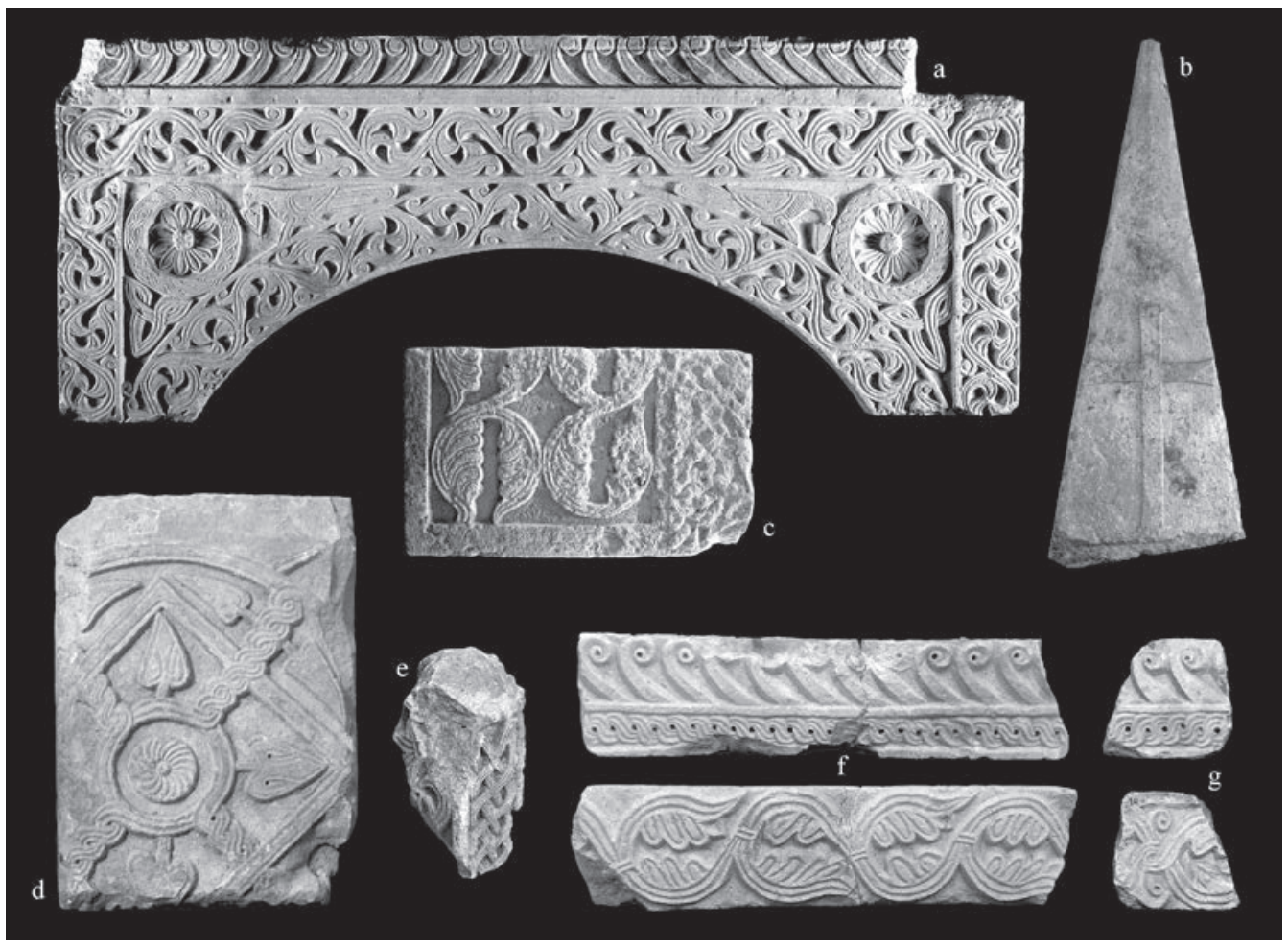

Fig. 11. Early pre-Romanesque fragments found in St. Chrysogonus church, late 8th and early 9th century

in Biskupija near Knin (fig. 10). Other fragments from St. Chrysogonus exhibit identical quality of production and specific treatment of various details, such as hooks, crosses, knotted circles and braids, and a motif characteristic of this workshop - pretzel. Therefore, it can be said that previous hypotheses about the work of the mentioned workshop on the church of St. Chrysogonus in Zadar which were based on only one architrave fragment are now fully confirmed.

Out of five fragments belonging to the second group of pre-Romanesque reliefs (fig. 11c-g), so far only a fragment of an altar screen slab and a fragment of pilaster have been analyzed (fig. 11c, uff ). Namely they were published quite 


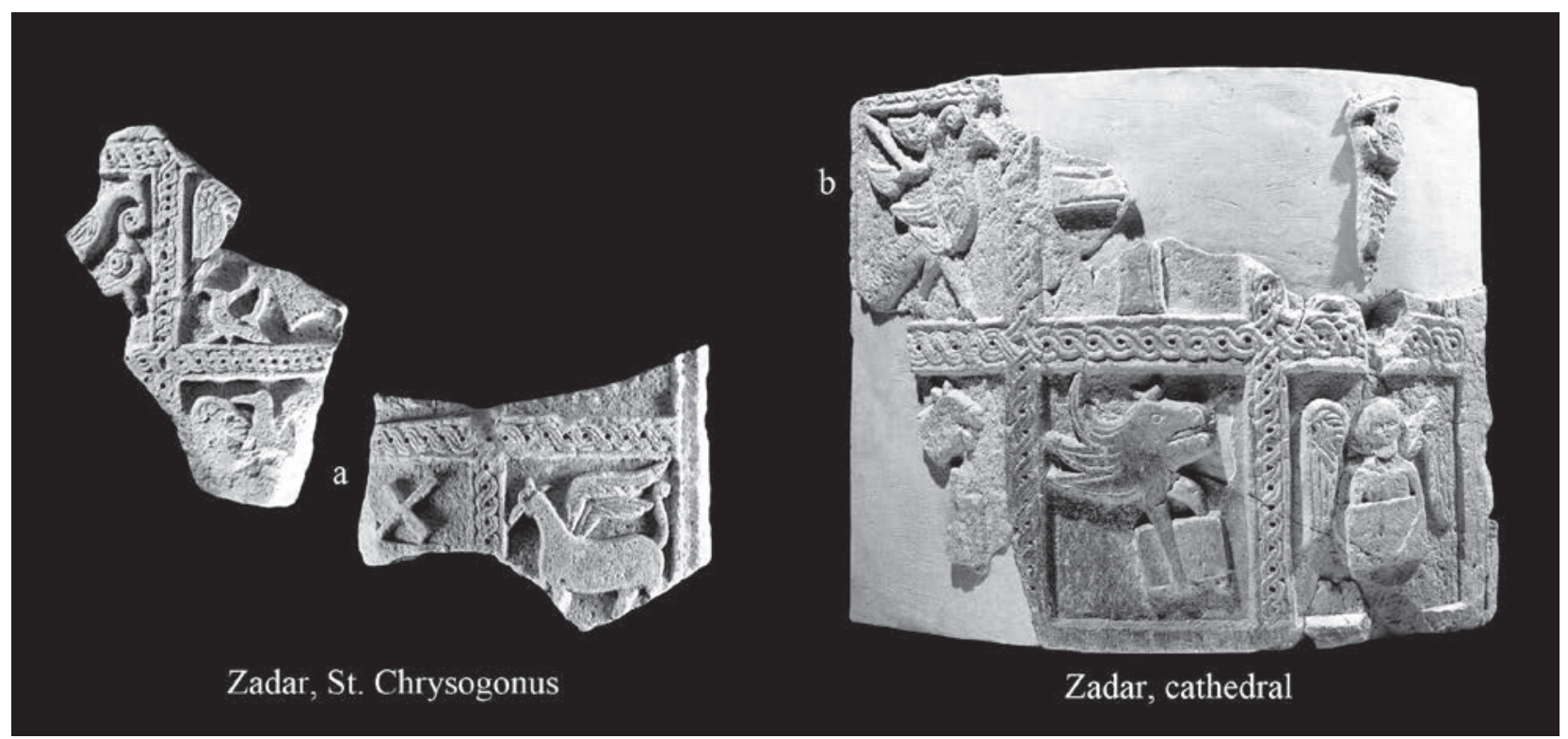

Fig. 12. Master of Zadar Ambos, Parapets of ambos from St. Chrysogonus church and Zadar cathedral, late 8th and early 9th century

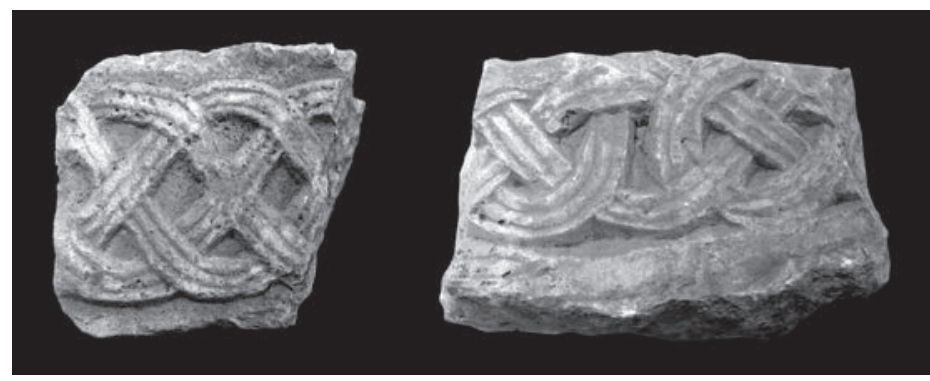

Fig. 13. Fragments of mature pre-Romanesque style found in St. Chrysogonus church, last decades of 9 th century

recently by Pavuša Vežić who dated them to the turn of the 9th century on the basis of sound arguments. ${ }^{14}$ This dating can be applied to the entire group of reliefs which comprises fragments belonging to different parts of the chancel screen such as architrave, pilaster and slabs. It is our opinion that two well known and repeatedly analyzed fragments of a quadrilateral ciborium can be added to this group. The first is an arcade which was found in 1888 in the pavement of the Romanesque church of St. Chrysogonus (fig. 11a) and the second is a panel of pyramidal ciborium roof with a relief cross (fig. 11b). It exhibits quality craftsmanship and was dated very broadly to the gth century, and once even to its second half. ${ }^{15}$ In our opinion they can be associated with the remaining five fragments which can be dated to the late 8 th and early 9th century. Moreover, it seems that all these fragments on the executable and iconographic level are very close to reliefs which we recognize as works of stone-carving production called Stonecarvers' Workshop of the Plutei from Zadar Cathedral and whose works were recognized in Zadar (especially in the cathedral), Galovac and Biograd, but also in Novalja on the island of Pag. ${ }^{16}$ Also, on two of them (fig. 11f-g) it is possible to identify the work of another stonecarver who made two fragments of parapet of the ambos found in Neviđane on the island of Pašman, and which are assumed

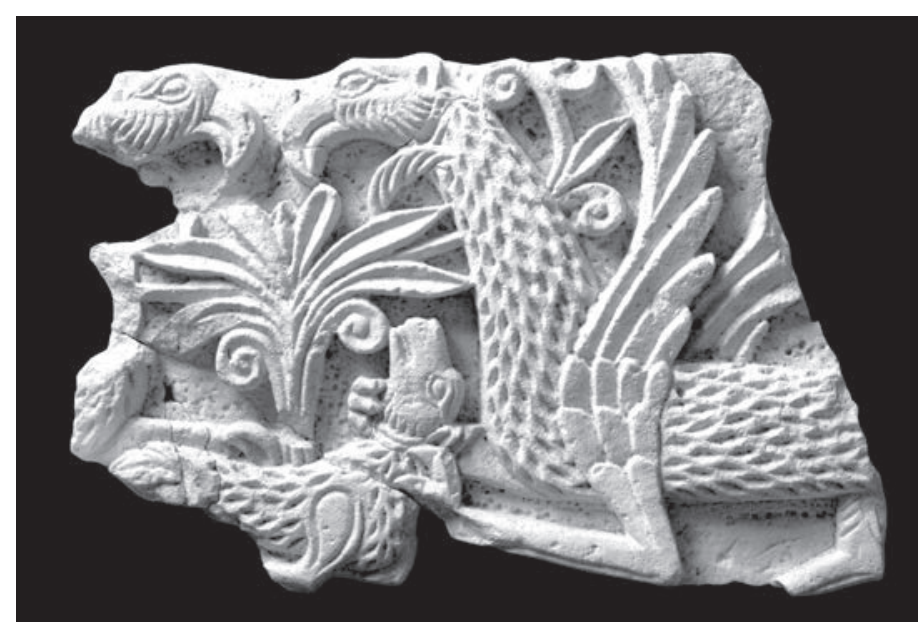

Fig. 14. Fragment of pluteus found in St. Chrysogonus church, after the begining of 12th century

to originate from the church of St. Chrysogonus in Zadar (fig. 12a). These two fragments are similar to the parapet of ambos from Zadar cathedral (fig. 12b) and were recognized as reliefs of stone-carving production called Master of Zadar Ambos. Activity of that master is also dated to the end of the 8th or the very beginning of the 9th century. ${ }^{17}$ Finally, it is obvious that - at least concerning early medieval liturgical furnishings - the church of St. Chrysogonus imitates the Zadar cathedral; the same will be happening in the Romanesque reconstruction too, in both architectural and sculptural level.

Out of three remaining reliefs found in St. Chrysogonus, two smaller fragments exhibit characteristics of mature pre-Romanesque style and they can be broadly dated to the last decades of the 9th century (fig. 13). On the other hand a larger fragment of altar screen slab bearing two griffins facing each other and catching a lamb with their claws (fig. 14) should be dated to the period after the beginning of the

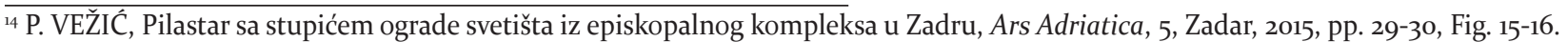

${ }^{15}$ N. JAKŠIĆ - E. HILJE, Umjetnička baština Zadarske nadbiskupije - Kiparstvo I (od IV. do XVI. stoljeća), Zadar, 2008, pp. 102-103, Fig. o21, with overall bibliography.

${ }^{16}$ I. JOSIPOVIĆ, Radionica plutejâ zadarske katedrale, Ars Adriatica, 4, Zadar, 2014, pp. 43-62.

${ }^{17}$ I. JOSIPOVIĆ, Il Maestro degli amboni zaratini, Hortus Artium Medievalium, 22, Zagreb - Motovun, 2016, pp. 443-45o, Fig. 1, 4.
} 
12th century as it exhibits characteristics of mature Romanesque style due to more pronounced voluminosity, more precisely rendered details of fur and feathers, and generally greater anatomical correctness in rendering animals extremities and proportions of their bodies. ${ }^{18}$

$$
* * *
$$

In all likelihood, more intensive building activities in the earlier monastery complex started as early as the mid-12th century. Information provided by Carlo Federico Bianchi by the end of the 18th century that the existing church of St. Chrysogonus was consecrated on May 4, 1175 was generally accepted in scholarly literature. ${ }^{19}$ It is assumed that the archbishop of Zadar Lampridius consecrated the church. Nearby monumental cathedral was renovated in the same period. However, it seems that finishing of the church construction as well as erecting of a new monastery next to its northern side continued during the following century. ${ }^{20}$ More extensive renovations of the Romanesque building and monastery complex were recorded during the Renaissance and Baroque periods from the 15 th to the 18 th century. ${ }^{21}$

The abbey of St. Chrysogonus was abolished in 1807 during the French administration when all other Benedictine monasteries on the eastern Adriatic coast were also abolished. ${ }^{22}$ First a lyceum and university were located in the area of the former abbey, then a gymnasium and convent school, and finally National Museum. ${ }^{23}$ Ćiril Metod Iveković managed extensive conservation and restoration works on the church in the period from 1911 to 1914, but there were no archaeological excavations ever carried out on the area of the monastery complex. ${ }^{24}$ During the Second World War the historical nucleus of Zadar was heavily damaged, including the abbey of St. Chrysogonus. ${ }^{25}$ Although the Romanesque church was only slightly damaged, a significant portion of walls of monastery buildings were demolished. However, prior to the post-war renovation walls of northeastern and south-eastern wing of the monastery were still visible, preserved to the height of the first and second floor, with doors in medieval form, walled with older windows. ${ }^{26}$ Unfortunately,

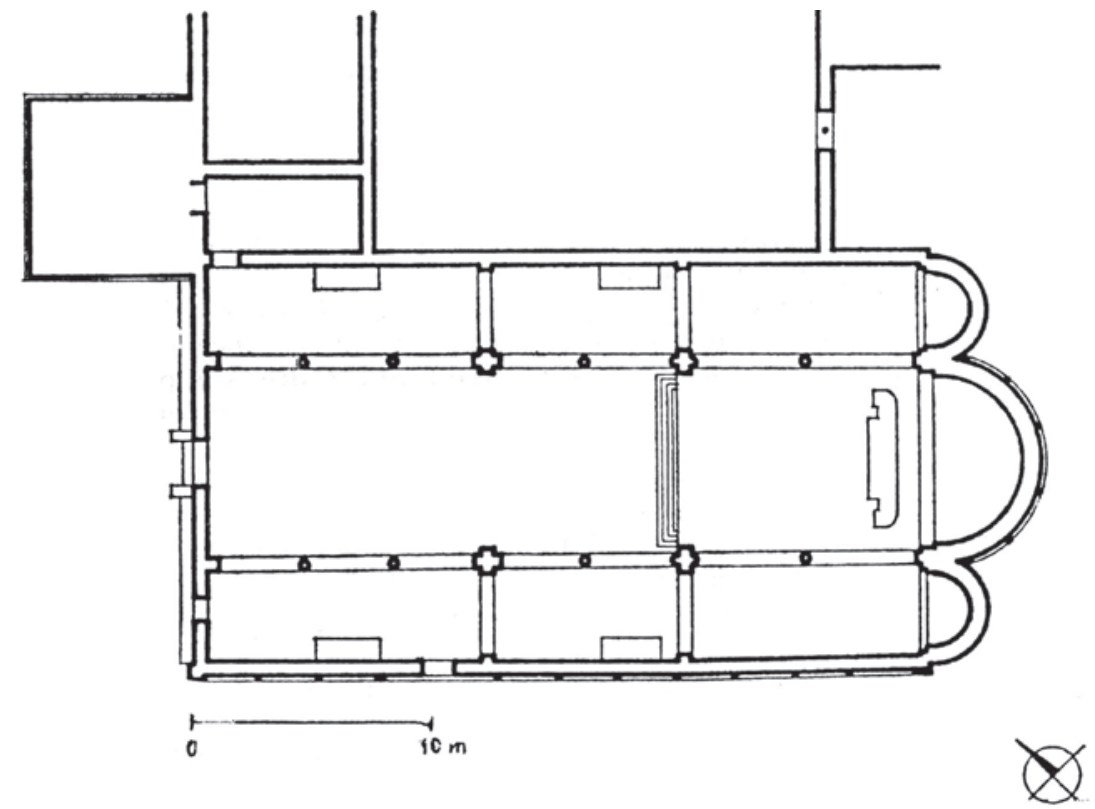

Fig. 15. Church of St. Chrysogonus, ground floor plan (N. KLAIĆ - I. PETRICIOLI, Zadar u srednjem vijeku do 1409., Zadar, 1976, p. 255)

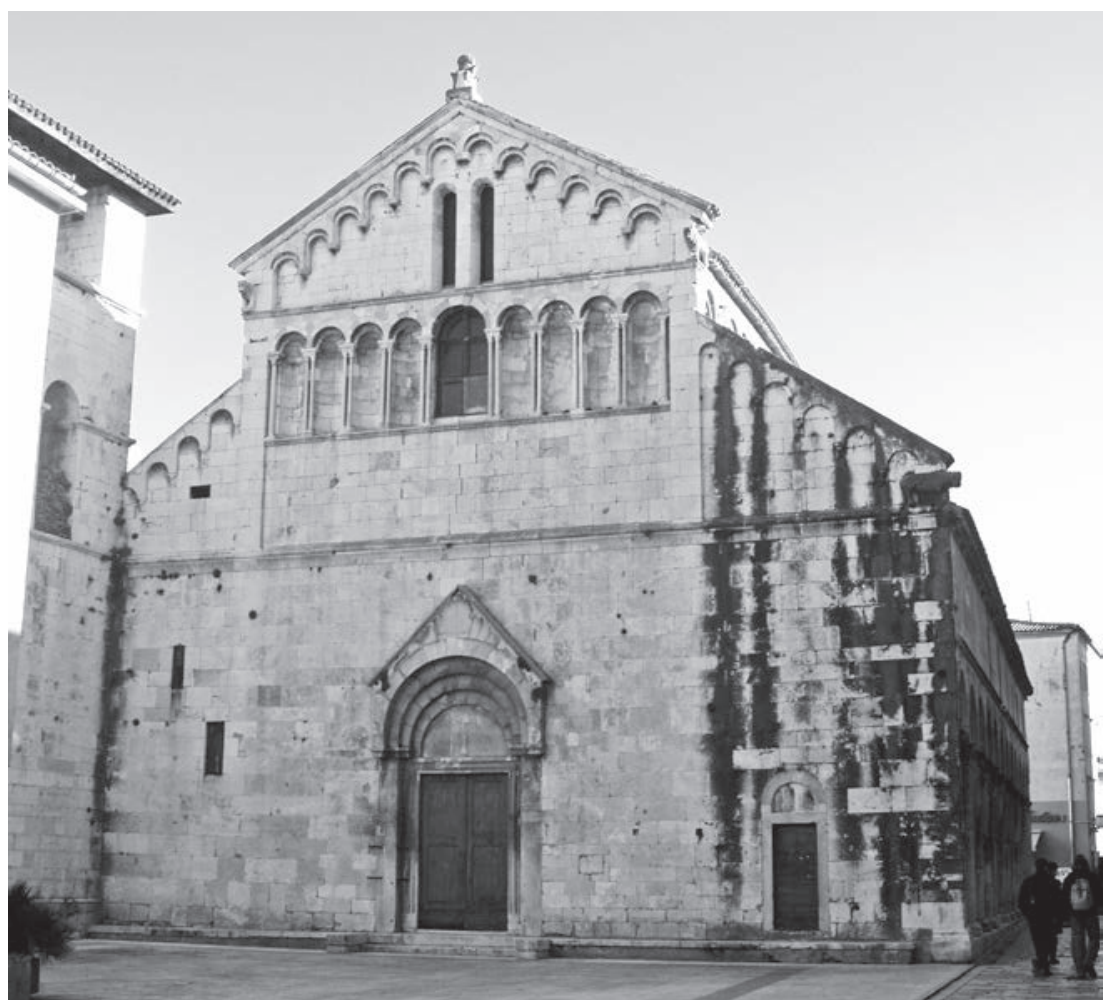

Fig. 16. Church of St. Chrysogonus, western front (photo: Emil Hilje)

$\overline{{ }^{18} \text { N. JAKŠIĆ - E. HILJE, op. cit. (n. 15), Zadar, 2008, pp. 142-143, Fig. } 043 .}$

${ }^{19}$ C. F. BIANCHI, Zara Cristiana, vol. I, Zadar, 1877, p. 302; Ć. M. IVEKOVIĆ, op. cit. (n. 2), p. 20; I. OSTOJIĆ op. cit. (n. 2), p. 53; N. KLAIĆ - I. PETRICIOLI, Zadar u srednjem vijeku do 1409., Zadar, 1976, p. 254; I. PETRICIOLI, op. cit. (n. 10), p. 202; P. VEŽIĆ, op. cit. (n. 4), p. 169.

${ }^{20}$ I. PETRICIOLI, op. cit. (n. 10), pp. 208-209; P. VEŽIĆ, op. cit. (n. 4), p. 169.

${ }^{21}$ See more in: P. VEŽıĆ, op. cit. (n. 4), pp. 172-177.

${ }^{22}$ I. OSTOJIĆ, op. cit. (n. 2), pp. 52-53.

${ }^{23}$ More about renovation(s)/adaptation(s) in the 19th c. in: M. STAGLIČIĆ, Obnova samostana sv. Krševana u 19. stoljeću, in: 10oo godina Samostana Svetog Krševana u Zadru: prilozi sa znanstvenog skupa održanog 11. i 12. prosinca 1986. u Zadru, u povodu 10oo. obljetnice Samostana Svetog Krševana i 30. obljetnice Filozofskog fakulteta u Zadru, (ed.) Ivo Petricioli, Zadar, 199o, pp. 231-240; Š. BATOVIĆ, Narodni muzej u samostanu sv. Krševana u Zadru, in: 1000 godina Samostana Svetog Krševana u Zadru: prilozi sa znanstvenog skupa održanog 11. i 12. prosinca 1986. u Zadru, u povodu 10oo. obljetnice Samostana Svetog Krševana i 30. obljetnice Filozofskog fakulteta u Zadru, (ed.) Ivo Petricioli, Zadar, 1990, pp. 241-258.

${ }^{24}$ More about conservation and restauration works on the church (1911-14) in: Ć. M. IVEKOVIĆ, op. cit. (n. 2), pp. 19-48, 53-57.

${ }^{25}$ See more in: A. MLIKOTA, Obnova i izgradnja povijesne jezgre Zadra nakon razaranja u Drugom svjetskom ratu (doctoral thesis), Zagreb, 2013, with overall bibliography.

${ }^{26}$ I. PETRICIOLI, op. cit. (n. 10), p. 197. 
in the 1950s a residential building was built above the south-eastern wing leaving only a small portion of wall with a two-mullion window and several fragments of capitals and bases which decorated the Romanesque cloister. ${ }^{27}$ Presently only the medieval church of the abbey is still preserved, as well as the ground floor and the first floor of the Renaissance bell-tower built next to its western front.

The church of St. Chrysogonus is a significant Romanesque religious monument on the eastern Adriatic coast (fig. 15). Although this medieval building had undergone many restorations, basically its original appearance was retained. The three-nave basilica measures $30 \mathrm{~m}$ in length without the apse, and $18 \mathrm{~m}$ in width. Its dimensions make it similar to the most representative Romanesque monuments preserved on the eastern Adriatic coast such as nearby cathedral of St. Anastasia, the cathedral of St. Lawrence in Trogir and the cathedral of St. Tryphon in Kotor. Among the contemporary Benedictine abbeys on the eastern Adriatic

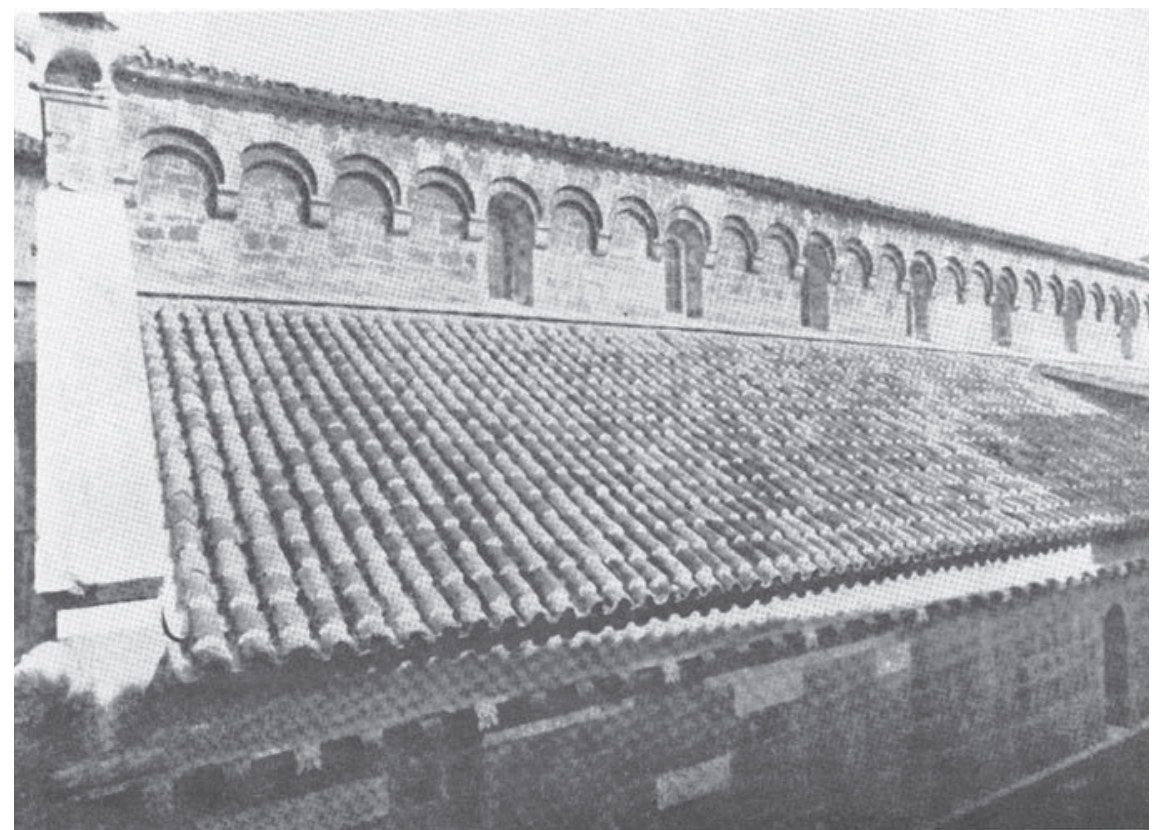
coast, it is important to mention its similarities with the church of St. Mary on the island of Lokrum, the most prominent abbey in Dubrovnik region, built most probably about the mid-12th century.

Western front of the church is well preserved (fig. 16). Although its south-eastern side was restored at the beginning of the zoth century, its original appearance was preserved for the most part. ${ }^{28}$ Harmonious Romanesque front was divided in three segments in its upper zone with shallow lesenes. Central part of gable is the largest and semicircular arches on consoles were preserved of its roof cornice. Two narrow round-headed windows are in the central part. Niches were made at the base of vertical string course, four on each side, while a large window opening was perforated subsequently under the central arch. It is possible that a window originally stood at this place, but we have no knowledge about its appearance and size. Between the semicircular niches and later opening are two small slender columns with capitals on each side. Two Romanesque portals were preserved at the front, the central one being more representative with slightly pronounced lunette and four round arches overtopped by steep gable. Most likely the portal was supported by (semi) columns on the lateral sides. Southern portal is smaller and rendered more simply, with a lintel and round shaped lunette. Out of the decoration of the Romanesque western front, only sculptures of two lions and a bull as symbol of Luke the Evangelist are preserved, located in its upper part. All three sculptures were made rather simply, with pronounced voluminosity and without emphasizing details. Anatomical details of their bodies are quite stylized, only heads (particularly lions') exhibit more quality craftsman-

\footnotetext{
${ }^{27}$ I. PETRICIOLI, Marginalije za obnovu Zadra, URBS, 2, Split, 1958.-59, p. 94; I. PETRICIOLI, op. cit. (n. 10), p. 197; I. BAVČEVIĆ, Klaustar samostana sv. Krševana u Zadru, in: 1000 godina Samostana Svetog Krševana u Zadru: prilozi sa znanstvenog skupa održanog 11. i 12. prosinca 1986. u Zadru, u povodu 10oo. obljetnice Samostana Svetog Krševana i 30. obljetnice Filozofskog fakulteta u Zadru, (ed.) Ivo Petricioli, Zadar, 1990, pp. 182-190.

${ }^{28}$ See more in: Ć. M. IVEKOVIĆ, op. cit. (n. 2), pp. 36, 38-39, Pl. XVII, XXI, XXIX.

${ }^{29}$ N. JAKŠIĆ - E. HILJE, op. cit. (n. 15), pp. 43-44, 171, Fig. 055(a), with overall bibliography.

${ }^{30}$ See more in: Ć. M. IVEKOVIĆ, op. cit. (n. 2), pp. 30-40, Pl. XVI-XXIV, XXX.

${ }^{31}$ More about the church of St. Mary on the island of Mljet and monuments in Kotor (St. Ana, Koleđata) in: I. TOMAS, Srednjovjekovne jednobrodne crkve s kupolom južne Dalmacije i Boke kotorske (doctoral thesis), Zagreb, 2014, pp. 260, 268, 301.
} 


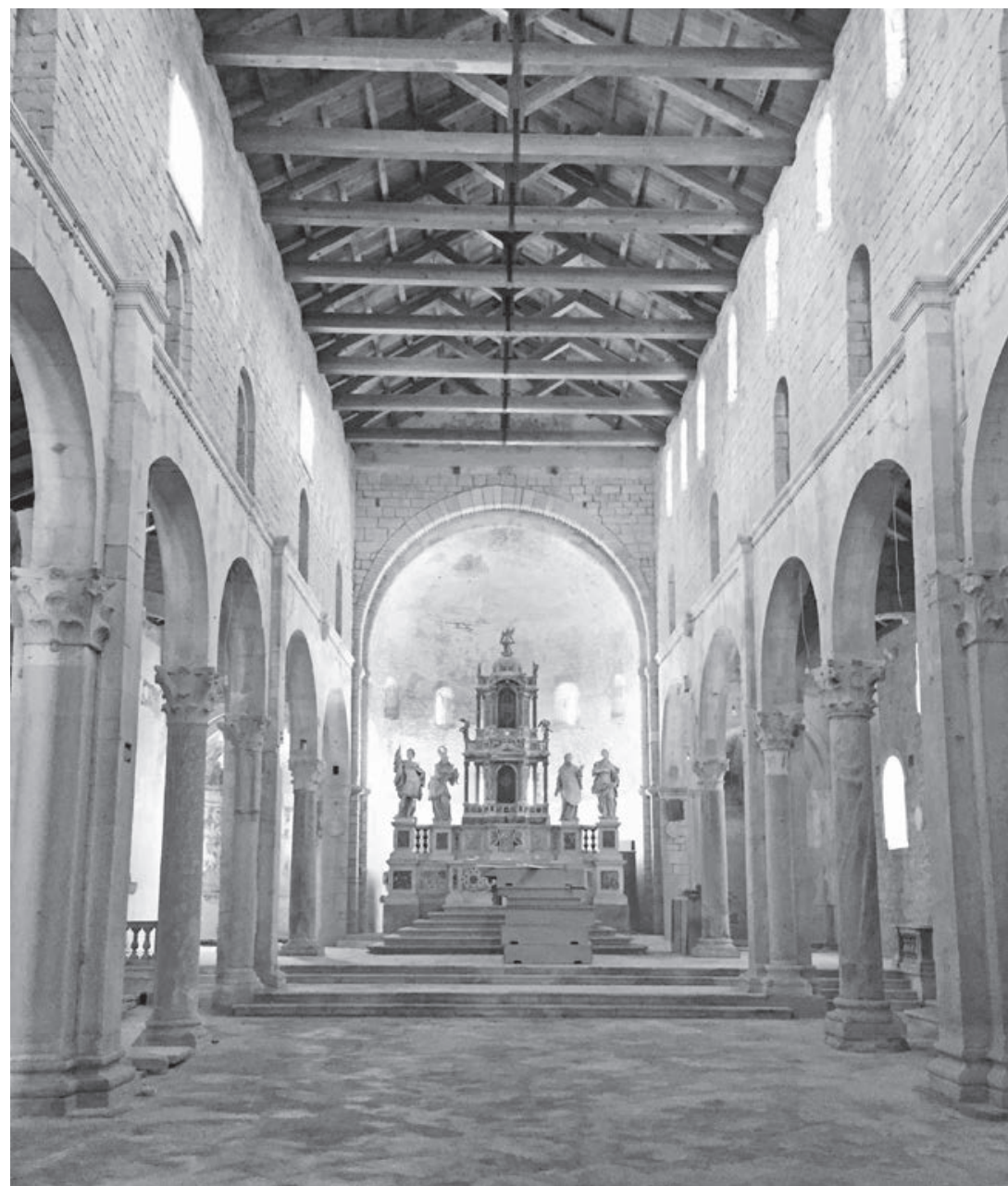

Fig. 18. Church of St. Chrysogonus, interior (photo: Ivana Tomas)

Central semicircular apse is much larger than the lateral ones. Its lower zone was segmented with six semicolumns rising from slightly moulded plinth, joining with semicircular arches at the top. The top of the semicircular arch of a centred window was preserved since a larger one was opened there during restoration in the Baroque period. ${ }^{32}$ In the upper third of the apse an outer gallery was constructed, consisting of semicircular arches on projecting consoles supported by small slender columns with cubic capitals. Upper part of the apse was additionally illuminated with five narrow windows. Although gallery on apse appears frequently in Romanesque architecture in Italy, it is not common on the eastern Adriatic monuments so that St. Chrysogonus in Zadar represents the only example of the kind in our regions. Roof cornice with slightly protruding semicircular arches on concave consoles was made on both lateral apses under the eaves. The original window was preserved on the southern apse as well.

Inner space of the basilica was divided by two pylons and four columns on each side, connected with semicircular arches (fig. 18). Pylons were placed in the central part and they were reinforced with arches on the lateral walls. Columns have round cross-section and they were made of precious marble and porphyry, originating from some Ro-

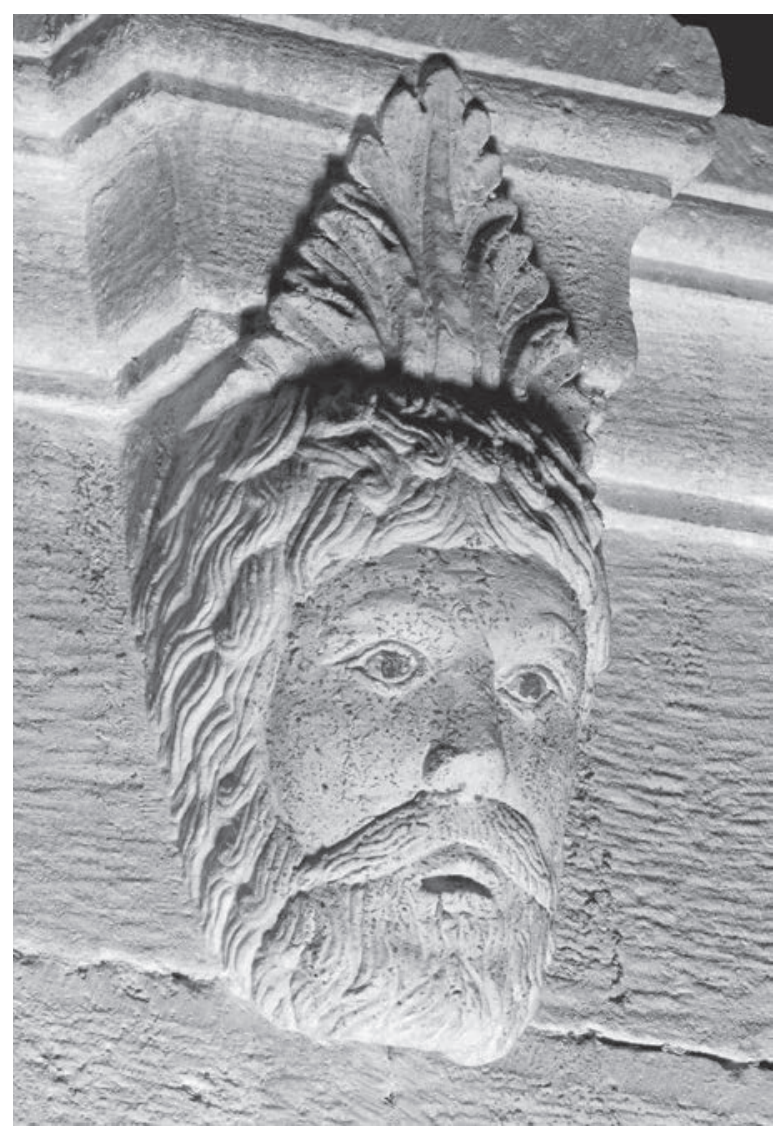

Fig. 19. Church of St. Chrysogonus, interior, figural consol (photo: Emil Hilje)

man-era building. All capitals are of Romanesque origin but made after antique models. ${ }^{33}$ Human figures were depicted on certain Romanesque capitals. Above the arcade zone is a cornice decorated with a sawteeth motif, and two figural consoles were installed over it. One depicts a human head (fig. 19), and the other lion's head. Both sculptures exhibit a higher quality of carving than the ones on the western front which is particularly evident on the male head. Tendency to certain realistic treatment of human face, and particularly detailed rendering of hair locks and beard might indicate that consoles were somewhat later than the figures on the western front. Above the cornice and consoles are narrow openings with semicircular ending. It is assumed that these were openings of (low) gallery located above the side aisles. Surface of the wall was made of well dressed stone blocks to the height of the mentioned openings while other walls were plastered and most likely painted in large part. Most probably Romanesque church was not vaulted but it had an open roof construction. ${ }^{34}$

Remains of Romanesque wall paintings were preserved in two layers of frescoes. The earlier layer is believed to originate from 1175 (time of church consecration) while the second layer is somewhat later, dated to the beginning of the 13th century. ${ }^{35}$ Having in mind historical circumstances of the period it is assumed that the Benedictine church, as well as the cathedral, was damaged by the crusaders in 1202 and that more extensive restoration followed. In addition to

\footnotetext{
32 See more in: Ć. M. IVEKOVIĆ, op. cit. (n. 2), pp. 39-40, Pl. XXV-XXVIII, XXXI.

${ }_{3}$ P. VEŽIĆ, Primjeri protorenesanse u Zadru, in: Renesansa i renesanse u umjetnosti Hrvatske: zbornik radova sa znanstvenih skupova "Dani Cvita Fiskovića" održanih 2003. i 2004. godine, (ed.) Predrag Marković, Zagreb, 2008, p. 445

${ }^{34}$ I. PETRICIOLI, op. cit. (n. 10), p. 200; P. VEŽIĆ, op. cit. (n. 4), p. 170

${ }^{34}$ See more in: E. HILJE - R. TOMIĆ, Umjetnička baština Zadarske nadbiskupije - Slikarstvo, Zadar, 2006, pp. 9-10, 79-84, Fig. o10 (a-f), with overall bibliography.
} 
wall paintings, it is possible that architectural sculpture was made as well, i. e. double arches with squat consoles on the outer walls of the central nave and two figurative consoles in the church interior. Their stylistic and morphological characteristics indicate that they should be dated to the period several decades later than previously believed. If this hypothesis could be accepted, it is then possible that some parts such as roof cornice were not finished until the consecration in 1175. The consecration does not necessarily mean that the building was finished completely, particularly regarding sculptural decoration of its upper parts such as roof cornice. Though this hypothesis seems possible, it remains in the realm of speculation. It is worth mentioning that except for frescoes decorating the church interior, conch of the main apse was ornamented with wall mosaic commissioned by Stana, daughter of Duke Petronja (Pietro, Petrana) in 1175 or 1219 according to some researchers. ${ }^{36}$

On the basis of the aforementioned we believe that an earlier sacral building existed on the location of the former Benedictine abbey of St. Chrysogonus, before the Romanesque church was built on the estate which was acquired later on. We cannot state with certainty whether it was a newly built pre-Romanesque building or possibly Early
Christian church which was renovated in the Early Middle Ages. Judging from the dimensions of the preserved preRomanesque sculpture it was a large building. Analysis of the early medieval sculpture indicates that the building was furnished with rich stone furnishings twice. The first instance refers to the late 8th or the early 9th century, and the second redecoration happened in the last decades of the gth century. Fragments in question were recognized as products of the Benedictine stonecarvers' workshop from the period of Duke Branimir. Since all pre-Romanesque fragments were identified as pieces of liturgical furnishings and not fragments of architectural sculpture, it is impossible to say if some more comprehensive building procedures on the building were undertaken.

In all likelihood, more intensive building activities on the earlier monastery complex started as early as the mid-12th century. Existing church of St. Chrysogonus was consecrated on May 4, 1175, period corresponding to its mature Romanesque characteristics. Having in mind that two layers of frescoes were found in the church, first one being dated to ca. 1175 i.e. time of its consecration, and the second to the period of its restoration at the beginning of the $13^{\text {th }}$ century, it is suggested that the roof cornice of the central nave was also made in the latter phase, as well as two figural consoles in the interior. Mentioned assumption is based on their stylistic and morphological characteristics and accordingly their dating was shifted several decades later.

${ }^{36}$ See more in: Ć. M. IVEKOVIĆ, op. cit. (n. 2), pp. 20-21; I. PETRICIOLI, op. cit. (n. 10), p. 2o8; I. FISKOVIĆ, Zidno slikarstvo Radovanova doba u Dalmaciji. Ikonološka razmatranja o zadarskim spomenicima, in: Majstor Radovan i njegovo doba. Zbornik radova međunarodnog znanstvenog skupa održanog u Trogiru 26.-30. rujna 1990. godine, (ed.) Ivo Babić, Trogir, 1994, pp. 201-216; E. HILJE - R. TOMIĆ, op. cit. (n. 35 ), p. 7. 